\title{
Induction of resistance in chili against Sclerotium rolfsii by plant-growth- promoting rhizobacteria and Anagallis arvensis
}

\author{
Warda Sharf, Arshad Javaid ${ }^{*}$ (D, Amna Shoaib and Iqra Haider Khan
}

\begin{abstract}
Background: Sclerotium rolfsii is a soil-borne fungal pathogen causing diseases in more than 500 plant species. It causes southern blight disease in chili. Chemical fungicides are used to control this disease, which also pollute the environment. The present study was designed to assess the potential of two species of plant-growth-promoting rhizobacteria (PGPR) viz. Bacillus megaterium and Pseudomonas fluorescence, and an allelopathic weed, Anagallis arvensis $L$., for the control of southern blight disease of chili.

Results: Initially, three PGPR strains, viz. B. megaterium OSR3, B. megaterium ZMR6, and P. fluorescence PF-097, were selected for their in vitro antagonistic assessment against $S$. rolfsii by dual culture technique on potato dextrose agar medium. OSR3 showed the highest antagonistic potential (68\%), followed by PF-097 (54\%) and ZMR6 (33\%). In a pot experiment, the two best strains of PGPR, namely OSR3 and PF-097, and dried biomass of $A$. arvensis (DBA) in different concentrations (1, 2 and 3\%) were used to manage southern blight disease of chili. In positive control treatment (S. rolfsii only), plant survival was low (73\%) than the negative control (100\%). OSR3, PF-097, OSR3 + 2\% DBA, and PF-097 + 2\% DBA significantly enhanced plant survival over positive control. The highest increase in chili growth over positive control was recorded due to OSR3, followed by PF-097 inoculations. Contents of carotenoid and chlorophyll were significantly decreased due to the fungal pathogen and improved due to PGPR strains. Application of the two PGPR strains and different concentrations of $A$. arvensis distinctly increased the catalase (CAT), peroxidase (POX), and polyphenol peroxidase (PPO) activities over positive control.
\end{abstract}

Conclusions: The present study concluded that PGPR strains B. megaterium OSR3 and P. fluorescence PF-097 can control southern blight disease effectively and increase growth and yield of chili.

Keywords: Bacillus megaterium, Sclerotium rolfsii, Biocontrol, Chili, Collar rot, Pseudomonas fluorescence

\section{Background}

Capsicum annum L. commonly known as chili belongs to family Solanaceae. Initially, its cultivation was limited to Southern and Central America which later on spread all over the world (Majid et al. 2016). In Pakistan, it is cultivated on 58.2 thousand hectares with an annual production of 74.6 thousand tons (Bashir et al. 2018).

\footnotetext{
*Correspondence: arshad.iags@pu.edu.pk; arshadjpk@yahoo.com Institute of Agricultural Sciences, University of the Punjab, Quaid-i-Azam Campus, Lahore 54590, Pakistan
}

\section{Springer Open}

(c) The Author(s). 2021 Open Access This article is licensed under a Creative Commons Attribution 4.0 International License, which permits use, sharing, adaptation, distribution and reproduction in any medium or format, as long as you give appropriate credit to the original author(s) and the source, provide a link to the Creative Commons licence, and indicate if changes were made. The images or other third party material in this article are included in the article's Creative Commons licence, unless indicated otherwise in a credit line to the material. If material is not included in the article's Creative Commons licence and your intended use is not permitted by statutory regulation or exceeds the permitted use, you will need to obtain permission directly from the copyright holder. To view a copy of this licence, visit http://creativecommons.org/licenses/by/4.0/.

The crop is affected by many fungal, bacterial and viral diseases resulting in huge economic losses. Among the fungal diseases, Sclerotium rolfsii, responsible for southern blight in chilies, is of major concern (Javaid et al. 2020). The observed disease symptoms are yellowing of plant leaves and the formation of dark brown lesions at collar region near the soil line which further lead to wilting of the whole plant (Mahadevakumar et al. 2018). It produces enormous sclerotia, which persist in soil for many years in the form of infected plant debris. It has a 
wide geographical host range, which makes its management challenging (Murthy et al. 2018).

The pathogen control may be achieved by applying tremendous volume of fungicides but their excessive usage has hazardous impact on environment as well as on human health (Keinath and DuBose 2017). Hence, nonchemical means of disease management include biocontrol agents and plant-based products that can serve as cheap and environmentally safe alternates to synthetic products (Wankhade et al. 2019). Recently, PGPR have attracted much attention in modern agriculture system because of their ability to promote plant growth and soil health (Mohamed et al. 2019). They have a distinct mechanism of action such as antibiosis, hyper parasitism, competition, and induced systemic resistance (Verma et al. 2019). The role of Bacillus megaterium and Pseudomonas fluorescence have been demonstrated against Fusarium, Rhizoctonia, Pythium, and Verticillium species (Omara et al. 2018; Guenoun et al. 2019; Zain et al. 2019). In addition to their ability to suppress the plant pathogens, these bacteria have the capacity to decompose organic matter in soil which plays an important role in plant production (Mohamed et al. 2019).

Anagallis arvensis, family Primulaceae, is an annual herb plant native to Europe, Africa and Asia (Soberon et al. 2017). Its chemical profile indicates the presence of sterols, terpenes, triterpenes, alkaloids, flavonoids, saponins, tannins, glycosides, and quinones with potent antifungal properties (Soberon et al. 2017). It is effective against several fungal plant pathogens including Rhizoctonia solani, Rhizopus stolonifera, Helminthosporium sativum, Phytopthora drechsleri, and Pythium aphanidermatum (Bahraminejad et al. 2011, 2013).

However, its role in controlling S. rolfsii, especially in combination with PGPR, has never been investigated. Therefore, the present study was carried out to determine the potential role of PGPR strains $B$. megaterium and $P$. fluorescence, and $A$. arvensis to control the southern blight disease of chili.

\section{Methods}

\section{Procurement of microorganisms}

The culture of pathogenic fungus S. rolfsii was obtained from Bio-fertilizers and Biopesticides Research Laboratory, Institute of Agricultural Sciences, University of the Punjab Lahore, Pakistan. Three PGPR strains, namely B. megaterium OSR3, B. megaterium ZMR4, and P. fluorescence PF-097, were obtained from the First Culture Bank of Pakistan. The fungus was sub-cultured on malt extract agar (MEA) plates and then incubated at $30{ }^{\circ} \mathrm{C}$ for 7 days. Sub-culturing of the bacterial strains was done on LBA (Luria-Bertani Agar) plates and then incubated at $37{ }^{\circ} \mathrm{C}$ for $24 \mathrm{~h}$. Culture plates of fungal and bacterial strains were stored in a refrigerator at $4{ }^{\circ} \mathrm{C}$.

\section{In vitro antagonistic interaction}

In vitro, the antagonistic isolates were screened using the dual culture technique on PDA (potato dextrose agar) medium, following the procedure of Mishra et al. (2017). Mycelia plug $(6 \mathrm{~mm})$ from the leading edge of a 7-day-old culture of $S$. rolfsii was placed in the center of a new PDA plate $(9 \mathrm{~cm})$. The bacterial strains PF-097, OSR3, and ZMR4 were inoculated by streaking $2 \mathrm{~cm}$ away from the fungal plug. In the control plate, only fungal disc was placed. Petri plates were placed at $30^{\circ} \mathrm{C}$ for incubation for 7 days. Six replicates of each treatment were made. The diameter of the fungal colony was recorded using a scale. Percentage inhibition of the radial growth of $S$. rolfsii by bacterial strains was determined after 7 days of incubation by using the following formula:

$$
\text { Growth inhibition }(\%)=(C-T) \times 100 / C
$$

where $T$ and $C$ represent radial growth of pathogen in treatment and control plates, respectively.

\section{Pot experiment}

A pot experiment was conducted by augmenting the soil with whole plant dried biomass of $A$. arvensis (DBA). Two bacterial strains namely PF-097 and OSR3 were selected from in vitro screening experiments and used alone as well as along with DBA. S. rolfsii (SR) inoculum was multiplied on pearl millet seeds, following the protocol of Javaid et al. (2020). For preparation of bacterial inocula, the two strains, namely OSR3 and PF-097, were cultured in LB broth media for $24 \mathrm{~h}$ at $30^{\circ} \mathrm{C}$. Culture flasks were then placed on the centrifuged machine at $4000 \mathrm{rpm}$ for $20 \mathrm{~min}$ and the pellet was placed in autoclaved $d . \mathrm{H}_{2} \mathrm{O}$. The concentration of the bacterial inoculum was calibrated to $1 \times 10^{7} \mathrm{cfu} \mathrm{m}^{-1}$ by quantifying optical density of 0.9 at $600 \mathrm{~nm}$ (Park et al. 2013).

Soil was disinfected by formalin solution (Javaid et al. 2020). Earthen pots of $(30 \mathrm{~cm}$ diameter) were filled by disinfected soil at $8 \mathrm{~kg}$ per pot. The pearl millet-based inoculum of the pathogen was mixed in each pot at $40 \mathrm{~g}$ per pot (@5 $\mathrm{g} \mathrm{kg}^{-1}$ soil), except in negative control. All the pots were irrigated and then left for 7 days for the development of inoculum of the pathogen. The whole plant dried material of $A$. arvensis was grinded thoroughly and mixed in the soil at 1,2 , and $3 \%(w / w)$, irrigated and left for 1 week. Thereafter, the bacterial inoculum suspension $\left(100 \mathrm{ml} \mathrm{pot}^{-1}\right)$ of each of PF-097 and OSR3 was poured into the soil of respective pots and mixed thoroughly (Zhang et al. 2011). The pots were irrigated and then left for 7 days. After that, 15day-old chili seedlings were sown in each pot (12 seedlings $\operatorname{pot}^{-1}$ ). The pots were placed under natural environmental conditions in open sunlight. 
The experiment was carried out in completely randomized design with triplicate set of each treatment and there were 13 treatments altogether:

$T_{1}$ Negative control

$T_{2}$ Positive control [only $S$. rolfsii (SR)]

$T_{3} 1 \% \mathrm{DBA}+\mathrm{SR}$

$T_{4} 2 \% \mathrm{DBA}+\mathrm{SR}$

$T_{5} 3 \% \mathrm{DBA}+\mathrm{SR}$

$T_{6}$ OSR3 + SR

$T_{7} 1 \% \mathrm{DBA}+\mathrm{OSR} 3+\mathrm{SR}$

$T_{8} 2 \% \mathrm{DBA}+\mathrm{OSR} 3+\mathrm{SR}$

$T_{9} 3 \% \mathrm{DBA}+\mathrm{OSR} 3+\mathrm{SR}$

$T_{10}$ PF-097 + SR

$T_{11} 1 \% \mathrm{DBA}+\mathrm{PF}-097+\mathrm{SR}$

$T_{12} 2 \% \mathrm{DBA}+\mathrm{PF}-097+\mathrm{SR}$

$T_{13} 3 \% \mathrm{DBA}+\mathrm{PF}-097+\mathrm{SR}$

All the chili plants were harvested after 90 days of transplantation. In order to check the effect of disease, number of plants survived in different treatments was recorded. After removing chili plants from the soil, the root and shoots were separated for measuring growth and biomass. Dry weight of chili plants were measured after drying at $70^{\circ} \mathrm{C}$. Data regarding yield was determined by taking number, and fresh and dry weight of fruits. Physiological changes in chili plants were determined at flowering stage, 40 days after transplanting of seedlings in the pots. Total chlorophyll content was determined following the procedure given by Arnon (1949). For this, the leaf extract prepared in $80 \%$ ethanol was centrifuged at $10,000 \mathrm{rpm}$ and the extract was checked for measurement of chlorophyll a $(645 \mathrm{~nm})$, chlorophyll b $(663 \mathrm{~nm})$ and carotenoids $(470 \mathrm{~nm})$ on a spectrophotometer. Likewise, the, total protein content was estimated using the protocol of Lowry et al. (1951). For estimation of total protein content, leaf sample $(0.5$ g) was crushed in $10 \mathrm{ml}$ of phosphate buffer $(0.1 \mathrm{M}, \mathrm{pH}$ 7.5) in pre-chilled pestle and mortar in liquid nitrogen, followed by centrifugation at $3000 \mathrm{rpm}$ for $10 \mathrm{~min}$ and addition of $1 \mathrm{ml}$ of reagent $\mathrm{C}$. The mixture was shaken for $10 \mathrm{~min}$, added with $0.1 \mathrm{ml}$ folinphenol reagent and finally incubated at room temperature for $30 \mathrm{~min}$. The total protein content was estimated at $650 \mathrm{~nm}$ by using standard curve of Bovine serum albumin. The activities of antioxidant enzymes, namely catalase (CAT0), peroxidase (POX0), and polyphenol oxidase (PPO), in leaves of chili estimation were estimated, following the procedure given by Shoaib et al. (2019a).

\section{Statistical analysis}

In vitro experiment was conducted, using 6 replicates, while pot study was carried out, using 3 replicates of each treatment. In both the cases, standard errors of means were calculated, using MS Excel software. Data of both the experiments were analyzed by one-way ANOVA and the treatment means were delineated by applying LSD test $(P \leq 0.05)$, using software Statistix 8.1.

\section{Results}

Interaction of PGPR with S. rolfsii

Among the three strains used, OSR3 showed the highest antagonistic activity and reduced growth of $S$. rolfsii by (68\%). Likewise, PF-097 also proved a very promising antagonistic PGPR strain as it inhibited the growth of the fungal pathogen by (54\%). In contrast, ZMR6 showed the least activity against $S$. rolfsii and retarded its in vitro growth by only $33 \%$ (Fig. 1). On the basis of their highly pronounced in vitro inhibitory activity against the fungal pathogen, PGPR strains OSR3 and PF-097 were selected for pot trial.

\section{Effect of soil amendments on plant survival}

In negative control, number of plants survived was 11, significantly reduced to 8 in positive control. Application of $1 \%$ plant biomass further reduced number of plants to 7. Increase in dose of dry biomass of A. arvensis (DBA) did not improve the situation. However, application of OSR3 significantly increased the plant survival up to the level of negative control. Application of PF-097 alone or combined with $2 \%$ DBA also markedly improved plant survival. In the rest of the treatments, number of plants survived was insignificantly different from the positive control (Fig. 2A).

\section{Effect of soil amendments on shoot growth}

Shoot length in negative control was $33.5 \mathrm{~cm}$ that was insignificantly reduced to $31.4 \mathrm{~cm}$ due to application of S. rolfsii. Application of DBA markedly reduced shoot length over negative as well as the positive control. By contrast, application of either of the two PGPR strains markedly enhanced this parameter. The effect on shoot length due to application of PF-097 was significant where $(21 \%)$ increase in shoot length was observed over positive control. The effect of combined application of DBA and the PGPR strains was insignificant (Fig. 2B). Shoot dry weight in negative control was $22.6 \mathrm{~g}$, significantly declined to $9.36 \mathrm{~g}$ in positive control $(59 \%$ decrease). The effect of DBA was insignificant when used alone or combined with OSR3. However, sole application of OSR3 significantly enhanced shoot dry weight by $156 \%$ over positive control. Likewise, application of PF097 also increased shoot biomass by $114 \%$ over positive control. Combined application of PF-097 and 2\% DBA also significantly increased shoo dry weigh of chili b $69 \%$ over positive control (Fig. 2C). 


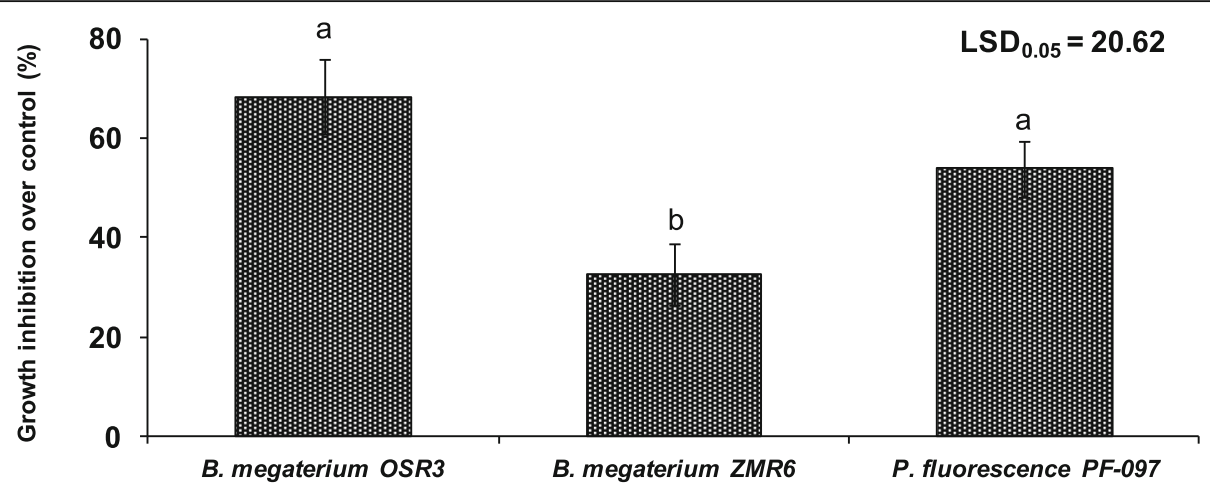

Fig. 1 Inhibition in radial growth of Sclerotium rolfsii due to interaction with different strains of Bacillus megaterium and Pseudomonas fluorescence. Vertical bars show standard errors of means of four replicates. Values with different letters at their top show significant difference $(P \leq 0.05)$ as determined by LSD test

\section{Effect of soil amendments on root growth}

The maximum root length $(15.33 \mathrm{~cm})$ was noted in negative control. Application of $S$. rolfsii suppressed the root length to $12.41 \mathrm{~cm}, 19 \%$ lower than that in negative control. Application of DBA either alone or in combination with PGPR strains further suppressed the root length (Fig. 3A). Root dry weight was the highest in negative control $(11.1 \mathrm{~g})$, diminished to $3.1 \mathrm{~g}$ in the positive control. Application of DBA did not improve the root dry biomass. Conversely, application of OSR3 improved the root biomass significantly and raised it (10.7 g) at par with the negative control. Application of PF097 also improved the situation $(7.45 \mathrm{~g})$; however, the effect was much lower than that of OSR3. Application of PGPR along with DBA gave root biomass lower than sole application of the two PGPR strains (Fig. 3B).

\section{Effect of soil amendments on yield}

The highest number of fruits was noted in negative control. S. rolfsii application significantly reduced this number by $80 \%$. Likewise, the pathogen reduced fresh and dry weight of chili by 89 and $87 \%$, respectively, over negative control. Some soil amendment treatments increased various yield-related parameters over control; however, the effect was insignificant (Fig. 4).

\section{Effect of soil amendments on plant physiology}

The highest chlorophyll content $\left(1.06 \mathrm{mg} \mathrm{g}^{-1} \mathrm{FW}\right)$ was recorded in negative control. In general, all the $S$. rolfsii inoculated treatments, either alone or combined with different soil amendments, showed markedly lower chlorophyll content than the negative control. In positive control, chlorophyll content was $0.62 \mathrm{mg} \mathrm{g}^{-1}$ that was significantly lower than the negative control by $42 \%$. Different doses of DBA insignificantly increased chlorophyll contents by $2-19 \%$. The highest increase in this parameter over positive control was due to application of OSR3 (60\%), followed by application of PF-097 (50\%).
Application of DBA along with either of the two PGPR strains reduced chlorophyll content than in PGPR strains alone (Fig. 5A).

Application of $S$. rolfsii in positive control resulted in an insignificant decrease in total protein content by $21 \%$ over negative control. All the soil amendments alleviated the biotic stress of $S$. rolfsii on this parameter and variably increased protein content by $15-69 \%$ over positive control. The highest increase was noted in OSR3 treatment (69\%), followed by OSR3 + 1\% DBA (60) as shown in (Fig. 5B).

Catalase (CAT) activity in negative control was $(0.66 \mathrm{U}$ $\left.\mathrm{min}^{-1} \mathrm{mg}^{-1}\right)$ protein, reduced to half $\left(0.33 \mathrm{U} \mathrm{min}^{-1} \mathrm{mg}^{-1}\right)$ on inoculation of $S$. rolfsii. All the soil amendment treatments, except PF-097 + 3\% DBA, significantly increased this parameter over positive control. As compared to positive control, there was (129-544\%) increase due to different treatments. Similar to that of chlorophyll content, the highest increase (544\%) was recorded in OSR3, followed by PF-097 (428\%) over positive control. Application of DBA negatively affected the activity of both the PGPR strains (Fig. 6A).

The effect of $S$. rolfsii application and different soil amendments on peroxidase (POX) activity was generally similar to that on CAT activity. In negative control, POX activity $\left(1.5 \mathrm{U} \mathrm{min}^{-1} \mathrm{mg}^{-1}\right)$ was decreased by $33 \%$ $\left(1.01 \mathrm{U} \mathrm{min}^{-1} \mathrm{mg}^{-1}\right)$ in positive control. Application of various soil amendments enhanced this parameter by (24-109\%) over positive control. The highest increase was due to OSR3 application (Fig. 6B).

The effect of the pathogen inoculation as well as other soil amendments on polyphenol ammonia lyase (PPO) activity was not much different than of these amendments on CAT and POX activities. PPO was $(0.52 \mathrm{U}$ $\left.\mathrm{min}^{-1} \mathrm{mg}^{-1}\right)$ in negative control and reduced to $(0.33 \mathrm{U}$ $\mathrm{min}^{-1} \mathrm{mg}^{-1}$ ) due to $S$. rolfsii application, i.e., lowered by $42 \%$. Soil amendments enhanced PPO by $27-184 \%$ over positive control. Application of OSR3 was the most effective treatment for improving PPO (Fig. 6C). 


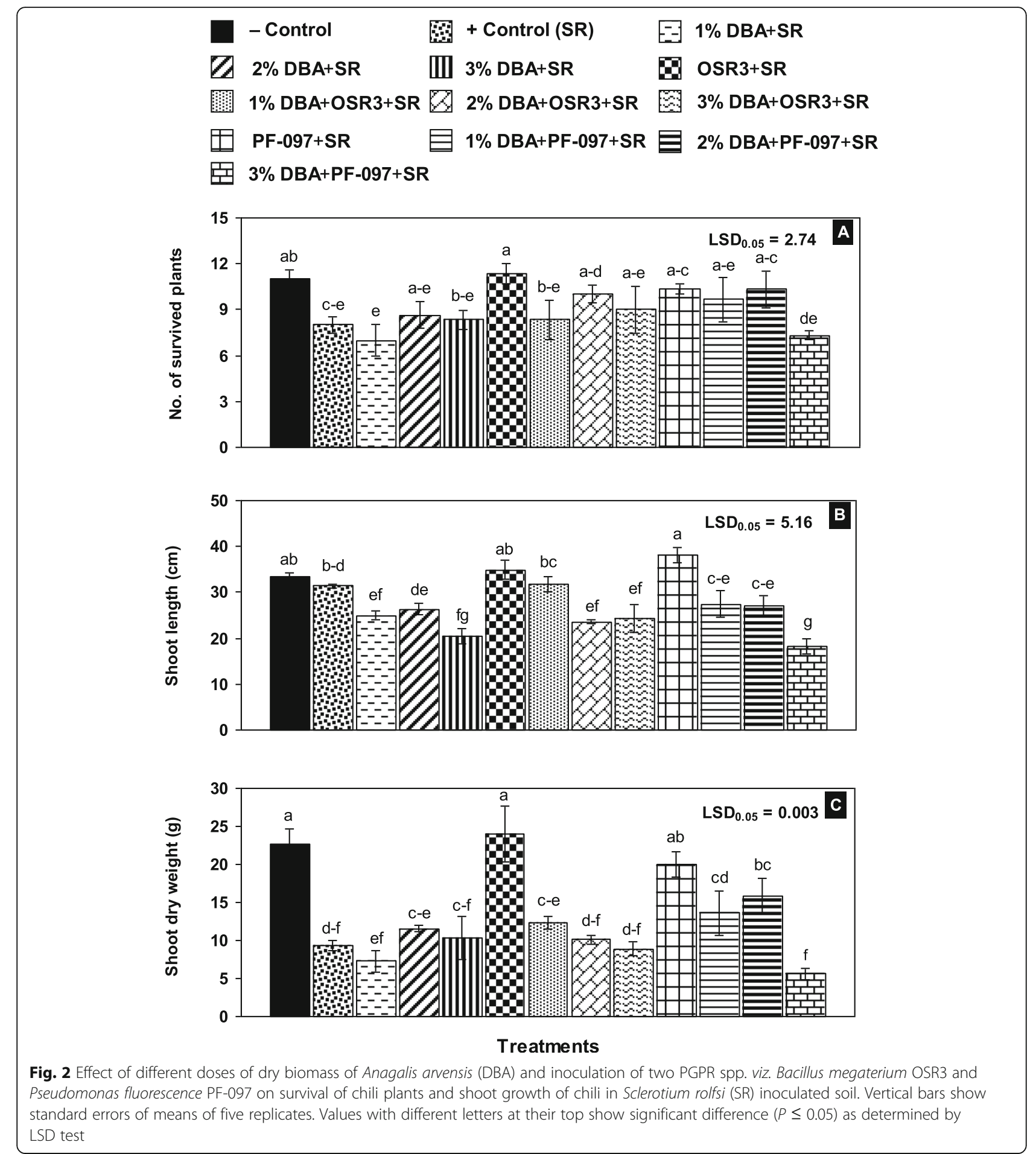

\section{Discussion}

In laboratory screening test, OSR3 exhibited the highest reduction $(68 \%)$ in the growth of $S$. rolfsii, followed by PF-097 (54\%). However, ZMR6 showed the least inhibition (32\%) against the pathogen. PGPR have attained a lot of attention as bioagents against numerous plant pathogens because they not only have the ability to prevent plant diseases but also provide nutrients to the plant and enhance their growth (Xiang et al. 2017). Bacillus spp. inhibited the growth of many pathogens by producing several metabolites (terpenes and polypeptide) and cell wall degrading enzymes such as chitinases (Shoda 2000). Romero et al. (2007) reported that Bacillus spp. produce several antibiotics such as iturin A that 


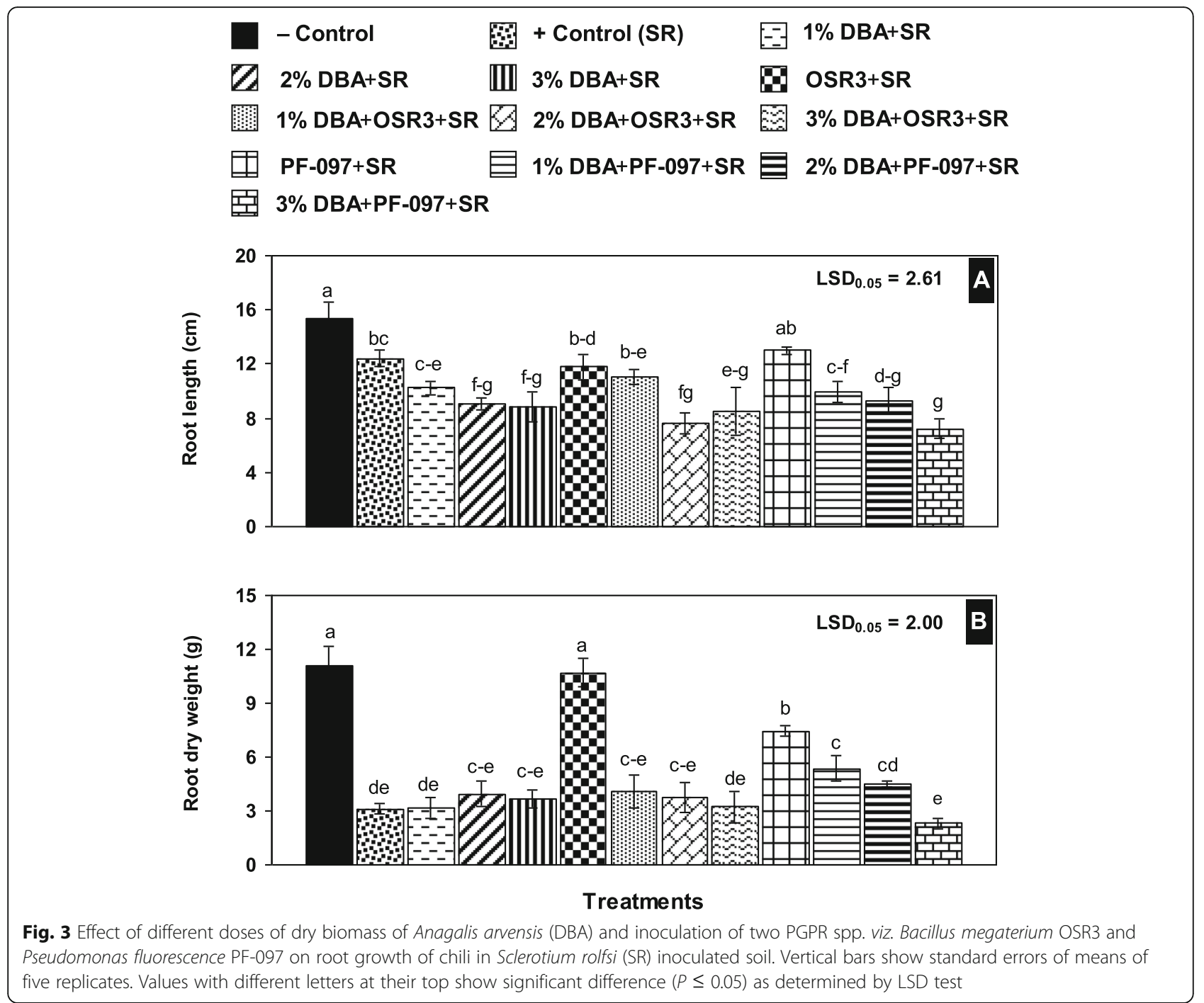

has the ability to inhibit the growth of $F$. oxysporum. Antagonistic potential of $B$. megaterium KU143 might be attributed to its volatile compounds (5-methyl-2-phenyl$1 \mathrm{H}$-indole), which proved effective in suppressing germination of conidia, germ tube elongation, and sporulation of Aspergillus spp. in stored rice grains (Mannaa and Kim 2018). The antifungal potential of P. fluorescnec was ascribed to its ability to produce hydrogen cyanide, hydrolytic enzyme I, phosphate solubilization, and siderophore to suppress the pathogen's mycelial growth (Sahni et al. 2019). In a previous study, P. fluorescence showed potential antifungal activity against Macrophomina phaseolina (Shanmugam et al. 2002) and R. solani (Ayyanar et al. 2004). Hence, the antifungal activity in PGPR might be attributed to its potential to directly inhibit pathogen growth through siderophores and phytochrome production, which also play an essential role in enhancing plant growth (Bashan et al. 2005), and indirectly by degrading pathogen cell wall through hydrolytic enzyme, e.g., chitinase, proteases and $ß-(1,3)$-glucanase (Goswami et al. 2016), antibiotic, secondary metabolites (cyanide), and formation of biofilms (Saraf et al. 2014).

In the present study, when the bacterial isolates OSR3 and PF-097 were added in the soil, the southern blight disease of chili was reduced significantly, and growth attributes of the plants improved significantly. In the previous study, PGPR strains have been recommended to use as soil amendment to suppress soil-borne pathogens (Zheng et al. 2011). Soil application of B. megaterium was used to improve rice yield through suppressing brown spot caused by Drechslera oryzae, while the antifungal potential ascribed to production of lipopeptide and polyoxine antibiotics by biocontrol agent (Islam and Nandi 2007). Bhat et al. (2015) revealed that P. fluorescence exhibited ability to control southern blight disease of bell paper and to enhance the yield, probably through phosphate solubilization, phytochromes production, and nitrogen fixation. Sahni et al. (2008) proved that 


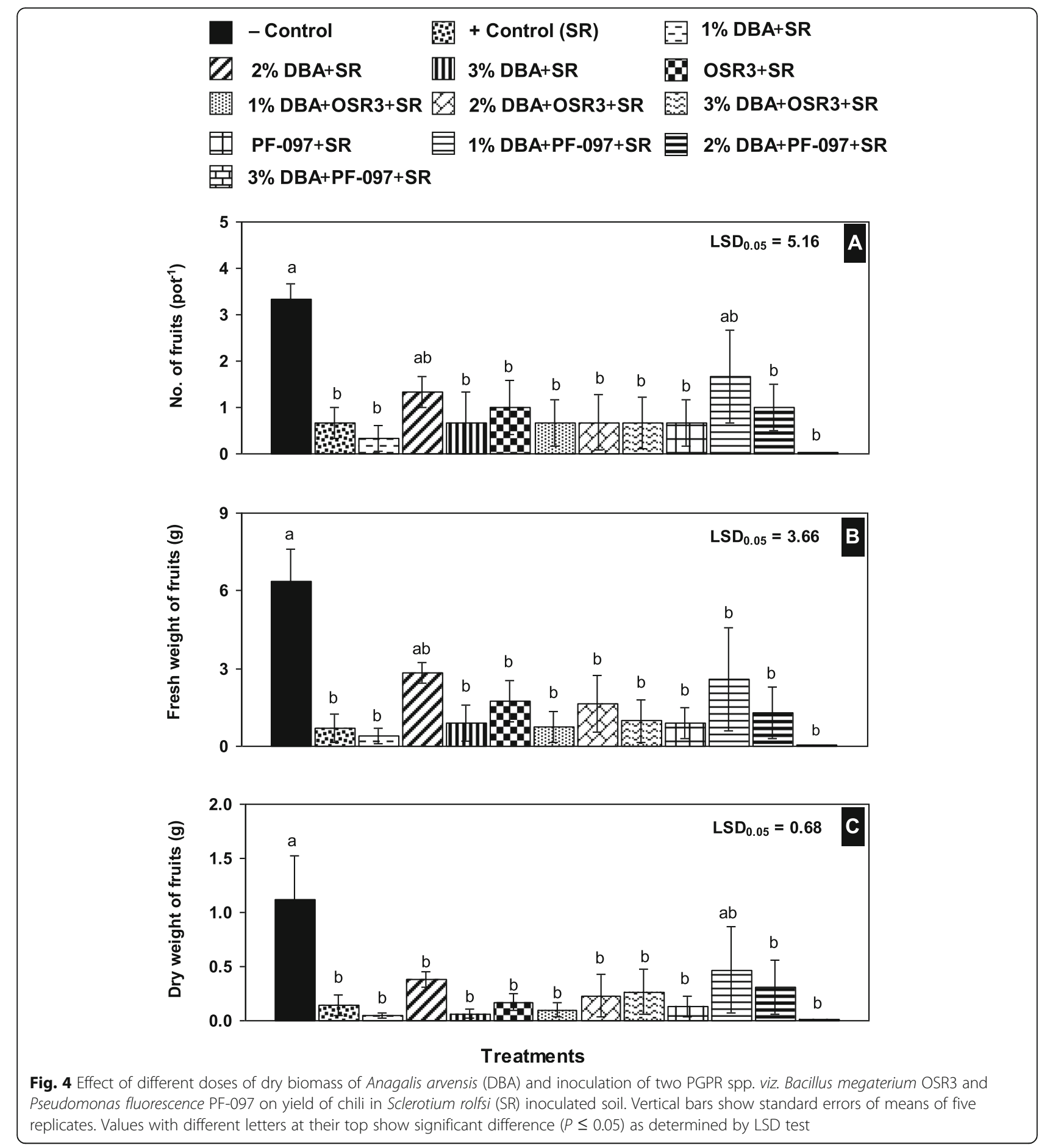

Pseudomonas spp. was highly effective to control the collar rot disease caused by $S$. rolfsii and to improve nutrient uptake of the plant when used with vermicompost. Induction of systemic resistance, synthesis of antimicrobial compounds, production of growth hormones, and competition for niches important for pathogen are some of the mechanisms that the PGPR could employ to alleviate disease stress in chili (Awan et al. 2019).
The disease was managed and the growth/yield attributes were improved when either of PGPR strains (OSR3 or PF-097) was applied along with dry biomass of A. arvensis. Similar results have been obtained previously due to the combined effect of soil amendment or biocontrol agents in Vigna mungo and $V$. radiata against charcoal rot caused by Macrophomina phaseolina (Shoaib et al. 2018) and in Cicer arietinum against collar 


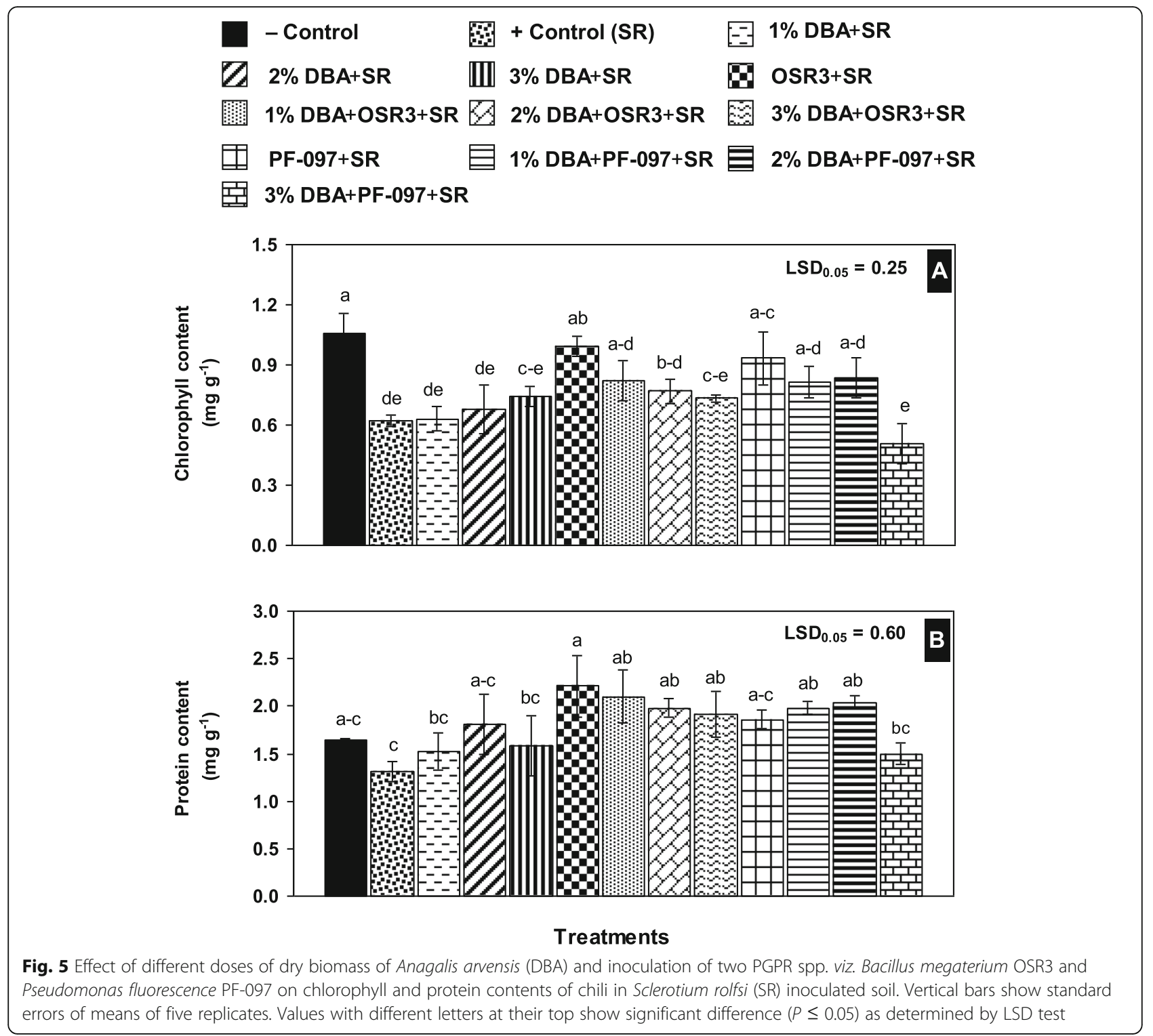

rot incited by S. rolfsii (Shoaib et al. 2019b). Likewise, combine application of PGPR strains such as Pseudomonas spp. and Bacillus spp. has been found highly antagonistic against Fusarium wilt caused by $F$. oxysporum. The biocontrol agents also increased plant height, and fruit and dry weight of tomato (Sundaramoorthy and Balabaskar 2013). Fungicidal action of dry biomass of $A$. arvensis and biocontrol bacteria may act as immune booster to increase resistance in chili plant against southern blight disease by conserving root system function, increasing nutrient availability and strengthening plant defense system in favor of better plant health (Shoaib et al. 2019b).

Results reveled that physio-chemical attributes in chili plants were drastically affected due to stress of $S$. rolfsii in positive control treatment than in the healthy plants in negative control, while application of plant biomass as organic amendment or bacteria as biofungicides exhibited variable influence on the investigated attributes. The pathogen stress in positive control treatments significantly decreased total chlorophyll content, which also resulted in reduction in the total protein content and activities of defenses related enzymes (CAT, POX and $\mathrm{PPO})$. The obvious trend of reduction in physicchemical attributes in plant under pathogen stress was reported earlier in many studied (Shoaib et al. 2018, 2019b; Awan et al. 2019). It could be attributed to chlorophyll degradation associated damaged to photosynthetic machinery that would cause disruption in the food manufacturing system. Plant immune system was likely to respond through over accumulation of reactive oxygen species (ROS) in response to $S$. rolfsii-induced 


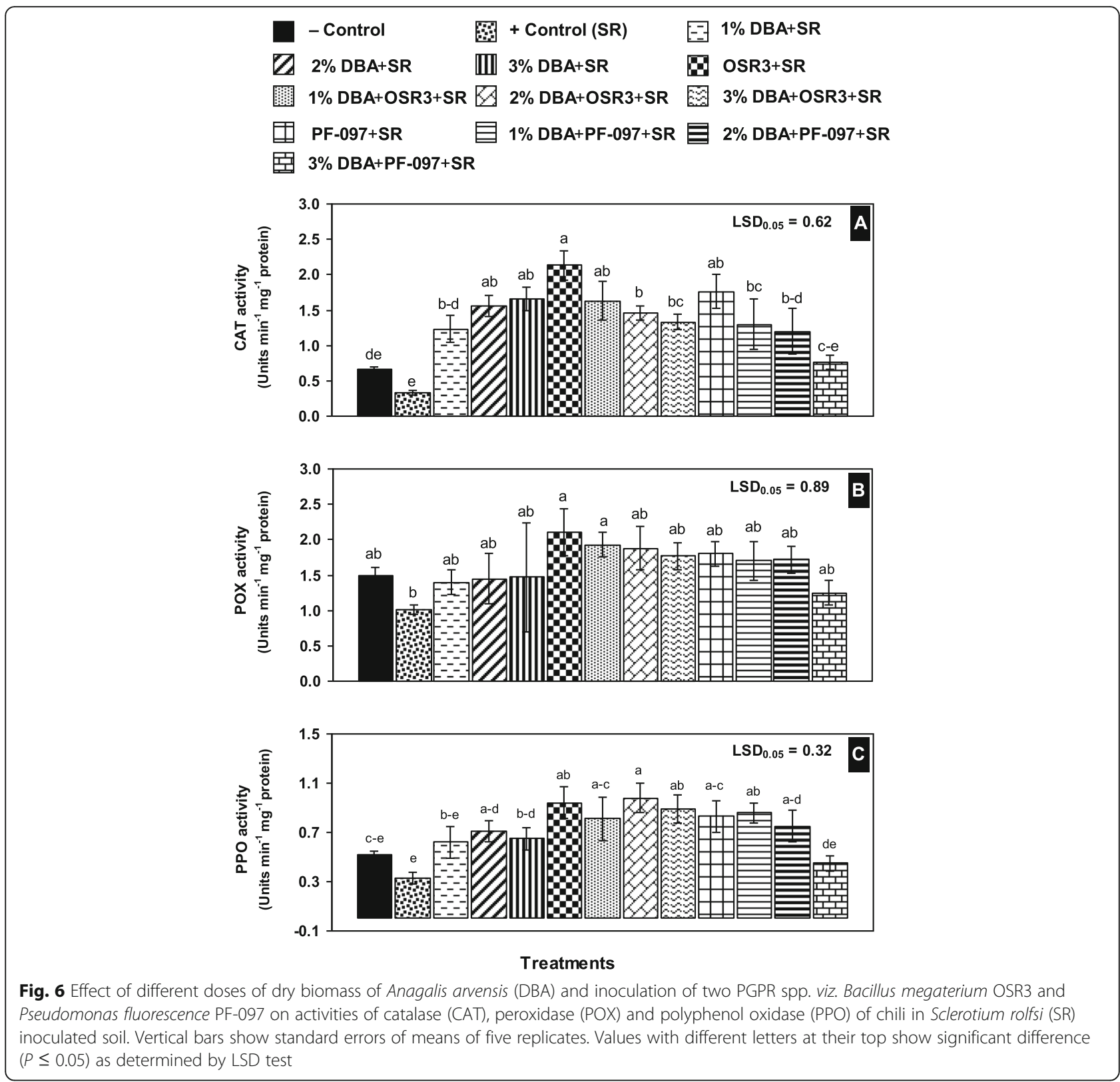

stress. However, reduction in activities of defense related enzymes may indicate that the host defense system had weakened, hence unable to facilitate with required level of protection against ROS, which may lead to the general oxidation of cell contents, nucleotide damage, and ultimately cell death (Shoaib et al. 2019a; Awan et al. 2019).

Soil inoculation with either B. megaterium or $P$. fluorescence as well as in combination with 1 and $2 \%$ dry plant biomass of $A$. arvenses significantly improved total chlorophyll content, protein content, and activities of antioxidant enzymes. However, separate effect of either biocontrol agent displayed more pronounced improvement than the bilateral interaction with dry biomass of A. arvenses, while biocontrol agent along with higher dose (3\%) of dry plant biomass exhibited adverse effect on different physio-chemical attributes. Moreover, $B$. megaterium was found to be more effective in improving the investigated physic-chemical attributes of the plants as compared to P. fluorescence. Therefore, total chlorophyll content, protein content, and activities of CAT, POX, and PPO were significantly improved by 60, 70, 600,109 , and $191 \%$, respectively, due to single application of B. megaterium and by $30,55,400,90$, and $170 \%$, respectively, due to interactive effect of $B$. megaterium with 1 or $2 \%$ dry plant biomass of $A$. arvenses. Likewise, $P$. fluorescence either alone or in combination with 1or $2 \%$ dry plant biomass of $A$. arvenses significantly improved total chlorophyll content, protein content, and 
activities of CAT, POX, and PPO by 30-51, 42-56, 300487, 70-78, and 132-159\%, respectively. Improvement in total chlorophyll content could be ascribed to stimulatory effect of biocontrol agent on rubisco activity as reported formerly by (Awan et al. 2019; Shoaib et al. 2019b). Increase in protein content could be ascribed to more availability of free amino acid for synthesis of nitrogenous compound (Rosa and Maiti 1995). So, change in total protein content due to different treatments under pathogenic stress conditions revealed different levels of resistance acquired by host plant against $S$. rolsii. CAT and POX may contribute in resistance by limiting the damage caused by free radicals and also act like antibiotic against invading pathogen (Awan et al. 2019). Babu et al. (2015) also documented that tomato plants treated with antagonistic bacteria showed improved resistance against early blight, which was associated with increased synthesis of antioxidant enzymes (CAT, POX, and PPO). POX activity also increased rigidity of plant cell wall by synthesizing cell-wall polymers (lignin and suberin), and elevation in POX further indicated its role as physical barriers against pathogen stress (Khurshid et al. 2017). Increase in activity of PPO after incorporation of bio fungicides may signify its importance in plant defense by oxidizing phenolic compounds into quinones that could create toxic environment for pathogen and could react with it. Besides, PPO could activate plant defense mechanism by inactivating of pathogen pectolytic enzyme (Shoaib et al. 2018).

\section{Conclusions}

It is concluded that OSR3 was the best PGPR strain to control $S$. rolfsii both in vitro and in vivo and to increase crop growth of chili. Disease management by bacterial antagonists might be associated with induction of resistance in plant through enhanced activity of antioxidant enzymes. $A$. arvensis was not suitable to be used for control of collar rot disease of chili as it exerted negative impact on crop growth through allelopathy.

\section{Abbreviations}

PGPR: Plan-growth-promoting rhizobacteria; MEA: Malt extract agar; ANOVA: Analysis of variance; DBA: Dry biomass of A. arvensis; CAT: Catalase; POX: Peroxidase; PPO: Polyphenol peroxidase

\section{Acknowledgements}

Not applicable.

\section{Authors' contributions}

WS conducted the study. AJ supervised the work, analyzed the data, and approved the final manuscript. AS supervised the part of study related to plant physiology. IHK contributed in paper writing. All authors have read and approved the manuscript.

\section{Funding}

Not applicable.

\section{Availability of data and materials}

The datasets used and/or analyzed during the current study are available from the corresponding author on reasonable request.

Ethics approval and consent to participate

Not applicable.

\section{Consent for publication}

Not applicable.

\section{Competing interests}

The authors declare that they have no competing interests.

Received: 20 May 2020 Accepted: 8 January 2021

Published online: 15 January 2021

\section{References}

Arnon DI (1949) Copper enzymes in isolated chloroplasts. Polyphenol oxidase in Beta vulgaris. J Plant Physiol 24:1-15

Awan ZA, Shoaib A, Khan KA (2019) Crosstalk of Zn in combination with other fertilizers underpins interactive effects and induces resistance in tomato plant against early blight disease. Plant Pathol I 35:330-340

Ayyanar K, Mohan L, Harish S, Radjacommare R, Amutha G, Chitra K, Karuppiah R, Mareeswari P, Rajinimala N, Angayarkanni T (2004) Biocontrol agents induce disease resistance in Phyllanthus niruri Linn against damping-off disease caused by Rhizoctonia solani. Phytopathol Mediterr 43:187-194

Babu AN, Jogaiah S, Nagaraj AK, Tran LSP (2015) Improvement of growth, fruit weight and early blight disease protection of tomato plants by rhizosphere bacteria is correlated with their beneficial traits and induced biosynthesis of antioxidant peroxidase and polyphenol oxidase. Plant Sci 231:62-73

Bahraminejad S, Abbasi S, Fazlali M (2011) In vitro antifungal activity of 63 Iranian plant species against three different plant pathogenic fungi. Afr J Biotechnol 10(72):16193-16201

Bahraminejad S, Amiri R, Ghasemi S, Fathi N (2013) Inhibitory effect of some Iranian plant species against three plant pathogenic fungi. Int J Agric Crop Sci 5(9):1002-1008

Bashan Y, Holguin G, de-Bashan LE. (2005) Azospirillum-plant relationships: physiological, molecular, agricultural, and environmental advances. Curr J Microbiol 50:521-577

Bashir MR, Atiq M, Sajid M, Mohsan M, Abbas W, Alam MW, Bashair M (2018) Antifungal exploitation of fungicides against Fusarium oxysporum f. sp. capsici causing Fusarium wilt of chili pepper in Pakistan. Environ Sci Pollut Res 25(7): 6797-6801

Bhat MN, Sardana HR, Singh D, Srivastava C, Ahmad M (2015) Evaluation of chemicals and bioagents against Sclerotium rolfsii causing southern blight of bell pepper (Capsicum annuum). Indian Phytopathol 68:97-100

Goswami D, Thakker JN, Dhandhukia PC (2016) Portraying mechanics of plant growth promoting rhizobacteria (PGPR): A review. Cogent Food Agric 2: 1127500

Guenoun K, Chattaoui M, Bouri M, Rhouma A, Naghmouchi K, Raies A (2019) Biological control of growth promoting rhizobacteria against Verticillium wilt of pepper plant. Biologia 74(3):237-250

Islam KZ, Nandi B (2007) Control of brown spot of rice by Bacillus megaterium. J Plant Dis Prot 87:241-246

Javaid A, Afzal R, Shoaib A (2020) Biological management of southern blight of chili by Penicillium oxalicum and leaves of Eucalyptus citriodora. Int J Agric Biol 23:93-102

Keinath AP, DuBose VB (2017) Management of southern blight on tomato with SDHI fungicides. Crop Prot 101:29-34

Khurshid S, Shoaib A, Javaid A, Akhtar F, Shafiq M, Qaisar U (2017) Management of Fusarium wilt of tomato by soil amendment with Cenchrus pennisetiformis under chromium stress. Physiol Mol Plant Pathol 97:58-68

Lowry OH, Rosebrough NJ, Farr AL, Randall RJ (1951) Protein measurement with the folin phenol reagent. J Biol Chem 193:265-275

Mahadevakumar S, Chandana C, Deepika YS, Sumashri KS, Yadav V, Janardhana GR (2018) Pathological studies on the southern blight of China aster (Callistephus chinensis) caused by Sclerotium rolfsii. Eur J Plant Pathol 151(4): 1081-1087

Majid MU, Awan MF, Fatima K, Tahir MS, Ali Q, Rashid B, Husnain T (2016) Phytophthora capsici on chilli pepper (Capsicum annuum L.) and its 
management through genetic and bio-control: a review. Zemdirbyste-Agric 103(4):419-430

Mannaa M, Kim KD (2018) Biocontrol activity of volatile-producing Bacillus megaterium and Pseudomonas protegens against Aspergillus and Penicillium spp. predominant in stored rice grains: study II. Mycobiology 46:52-63

Mishra VK, Passari AK, Chandra P, Leo W, Kumar B, Uthandi S, Thankappan S, Gupta VK, Singh BP (2017) Determination and production of antimicrobial compounds by Aspergillus clavatonanicus strain MJ31, an endophytic fungus from Mirabilis jalapa L. using UPLC-ESI-MS/MS and TD-GC-MS analysis. PLoS One 12:e0186234

Mohamed I, Eid KE, Abbas MH, Salem AA, Ahmed N, Ali M, Fang C (2019) Use of plant growth promoting rhizobacteria (PGPR) and mycorrhizae to improve the growth and nutrient utilization of common bean in a soil infected with white rot fungi. Ecotox Environ Safe 171:539-548

Murthy PS, Kumari JPR, Basavaraju N, Janardhan D, Devamma MN (2018) In vitro influence of bio-controlling agents against Sclerotium rolfsii causing stem rot sickness of groundnut (Arachis hypogaea L.). Pharm Innov 7:05-08

Omara AED, Nour El-Din M, Hauka F, Hafez A, El-Nahrawy S, Ghazi A, Fusco V (2018) Suppression of Rhizoctonia solani damping-off in soybean (Glycine max L.) by plant growth promoting Rhizobacteria strains. Environ Biodivers Soil Secur 2:39-49

Park JW, Balaraju K, Kim JW, Lee SW, Park K (2013) Systemic resistance and growth promotion of chili pepper induced by an antibiotic producing Bacillus vallismortis strain BS07. Biol Control 65:246-257

Romero D, Perez-Garcia A, Veening JW, de Vicente A, Kuipers OP (2007) Transformation of undomesticated strains of Bacillus subtilis by protoplast electroporation. J Microbiol Method 66:556-559

Rosa DL, Maiti RK (1995) Biochemical mechanism in glossy sorghum lines for resistance to salinity stress. Plant Physiol 146:515-519

Sahni S, Prasad BD, Ranjan T (2019) Biocontrol of Sclerotium rolfsii using antagonistic activities of pseudomonads. Curr J Appl Sci Technol 35:1-9

Sahni S, Sarma BK, Singh KP (2008) Management of Sclerotium rolfsii with integration of non-conventional chemicals, vermicompost and Pseudomonas syringae. World J Microbiol Biotechnol 24:517-522

Saraf M, Pandya U, Thakkar A (2014) Role of allelochemicals in plant growth promoting rhizobacteria for biocontrol of phytopathogens. Microbiol Res 169:18-29

Shanmugam V, Ramanathan A, Samiyappan R (2002) Interaction of Pseudomonas fluorescens with Rhizobium for their effect on the management of peanut root rot. Phytoparasitica 30:169-176

Shoaib A, Awan ZA, Khan KA (2019a) Intervention of antagonistic bacteria as potential inducer of disease resistance in tomato to mitigate early blight. Sci Hort 252:20-28

Shoaib A, Munir M, Javaid A, Awan ZA, Rafiq M (2018) Anti-mycotic potential of Trichoderma spp. and leaf biomass of Azadirachta indica against the charcoal rot pathogen, Macrophomina phaseolina (Tassi) Goid in cowpea. Egypt J Biol Pest Control 28:26

Shoaib A, Shehzad A, Javaid A, Akhtar S, Awan ZA (2019b) Evaluation of biocontrol strategies and its synergistic interaction permitting the chickpea plant to trigger the appropriate defense responses against Sclerotium rolfsii. Biologia 65(2):329-334

Shoda M (2000) Bacterial control of plant diseases. J Biosci Bioeng 89:515-521

Soberon JR, Sgariglia MA, Pastoriza AC, Soruco EM, Jager SN, Labadie GR, Vattuone MA (2017) Antifungal activity and cytotoxicity of extracts and triterpenoid saponins obtained from the aerial parts of Anagallis arvensis L. J Ethnopharmacol 203:233-240

Sundaramoorthy S, Balabaskar P (2013) Evaluation of combined efficacy of Pseudomonas fluorescens and Bacillus subtilis in managing tomato wilt Caused by Fusarium oxysporum f. sp. Iycopersici (Fol). J Plant Pathol 12:154161

Verma PP, Shelake RM, Das S, Sharma P, Kim JY (2019) Plant growth-promoting rhizobacteria (PGPR) and fungi (PGPF): potential biological control agents of diseases and pests. In: Microbial Interventions in Agriculture and Environment. Springer, Singapore, pp 281-311

Wankhade SM, Patil CU, Padghan PR, Pardey VP (2019) Efficacy of fungicides, plant extracts and bio-agents against Sclerotium rolfsii incitant of collar rot of betelvine. J Plant Dis Sci 14(2):138-140

Xiang N, Lawrence KS, Kloepper JW, Donald PA, McInroy JA, Lawrence GW (2017) Biological control of Meloidogyne incognita by spore-forming plant growth promoting rhizobacteria on cotton. Plant Dis 101:774-784
Zain M, Yasmin S, Hafeez FY (2019) Isolation and characterization of plant growth promoting antagonistic bacteria from cotton and sugarcane plants for suppression of phytopathogenic Fusarium species. Iran J Biotechnol 17(2): e1974

Zhang ZF, Zhang ML, WU FJ, Peng WX (2011) Analysis on function components and bio-health function of Pinus massoniana Lamb biomass. Appl Mech Mater 55:157-160

Zheng Y, Xue QY, Xu LL, Xu Q, Lu S, Gu C, Guo JH (2011) A screening strategy of fungal biocontrol agents towards Verticillium wilt of cotton. Biol Control 56: 209-216

\section{Publisher's Note}

Springer Nature remains neutral with regard to jurisdictional claims in published maps and institutional affiliations.

\section{Submit your manuscript to a SpringerOpen ${ }^{\circ}$ journal and benefit from:}

- Convenient online submission

Rigorous peer review

- Open access: articles freely available online

- High visibility within the field

- Retaining the copyright to your article

Submit your next manuscript at $\boldsymbol{\nabla}$ springeropen.com 